\title{
ANALISIS KEMAMPUAN PEMAHAMAN KONSEP MATEMATIS PESERTA DIDIK SMP PADA MATERI ALJABAR
}

\author{
Rina Nur Anisa ${ }^{1}$, Angra Meta Ruswana ${ }^{2}$, Lala Nailah Zamnah ${ }^{3}$ \\ 1,2,3 Program Studi Pendidikan Matematika, Universitas Galuh, JI. R. E. Martadinata No.150, Ciamis, Indonesia \\ Pendidikan Matematika Universitas Galuh Ciamis $^{3}$ \\ Email: nuranisarina9@gmail.com
}

\begin{abstract}
This study aims to find students' ability to understand mathematical concepts of Algebra material at Junior High School. This research uses a qualitative approach with a case study method. The research subjects are six students of class VII in one of Junior High Schools in Culamega, Tasikmalaya Regency. Data collection includes written test, interview, and documentation. The data are analyzed based on four indicators of mathematical understanding ability, namely 1) mechanical understanding which is characterized by doing memory activities regularly, applying formulas and doing simple calculation; 2) inductive understanding is applying formulas or concepts in simple cases or in similar cases; 3) rational understanding is proving the truth of a formula and theorems; and 4) intuitive understanding which is predicting the truth with certainty (without hesitation) before analyzing it further. The results showed that: 1) Almost all students in the low, medium and high categories were able to remember and apply formulas routinely and doing simple calculation; 2) Students with moderate and high mathematical understanding abilities tend to be able to apply formulas and perform calculations correctly. Meanwhile, students with low mathematical comprehension skills have not been able to apply formulas and perform calculations correctly; 3) Almost all students in the low, medium and high categories have not been able to prove the truth of a formula or theorem; and 4) Almost all students in the low, medium and high categories are able to estimate the truth of the formula (answer) although there are some students who are less able to predict the formula to be used with certainty.
\end{abstract}

Keywords: Mathematical understanding ability, Algebra

\begin{abstract}
ABSTRAK
Penelitian ini bertujuan untuk mengetahui kemampuan pemahaman konsep matematis siswa SMP kelas VII pada materi Aljabar. Penelitian ini menggunakan pendekatan kualitatif dengan metode studi kasus. Subjek penelitian adalah siswa kelas VII di salah satu SMP Negeri di Culamega Kabupaten Tasikmalaya sebanyak enam orang. Pengumpulan data meliputi tes tertulis, wawancara, dan dokumentasi. Data dianalisis berdasarkan empat indikator kemampuan pemahaman matematis, yaitu pemahaman mekanikal yang dicirikan oleh kegiatan mengingat dan menerapkan rumus secara rutin dan menghitung secara sederhana, pemahaman induktif yaitu menerapkan rumus atau konsep dalam kasus sederhana atau dalam kasus serupa, pemahaman rasional yaitu membuktikan kebenaran suatu rumus dan teorema serta pemahaman intuitif yaitu memperkirakan kebenaran dengan pasti (tanpa ragu-ragu) sebelum menganalisis lebih lanjut. Hasil penelitian menunjukkan bahwa: 1) Hampir semua siswa berkategori rendah, sedang dan tinggi mampu mengingat dan menerapkan rumus secara rutin dan menghitung secara sederhana; 2) Siswa dengan kemampuan pemahaman matematis sedang dan tinggi cenderung mampu menerapkan rumus dan melakukan perhitungan dengan tepat. Sedangkan siswa dengan kemampuan pemahaman matematis rendah belum mampu menerapkan rumus dan melakukan perhitungan dengan tepat; 3) Hampir semua siswa berkategori rendah, sedang dan tinggi belum mampu membuktikan kebenaran suatu rumus atau teorema; dan 4) Hampir semua siswa berkategori rendah, sedang dan tinggi mampu memperkirakan kebenaran rumus (jawaban) meskipun terdapat beberapa siswa yang kurang mampu dalam memperkirakan dengan pasti rumus yang hendak digunakan.
\end{abstract}

Kata Kunci: Kemampuan pemahaman matematis, Aljabar

Cara sitasi: Anisa, R. N., Ruswana, A. M., \& Zamnah, L. N. (2021). Analisis Kemampuan Pemahaman Konsep Matematis Peserta Didik Smp Pada Materi Aljabar. J-KIP (Jurnal Keguruan dan IImu Pendidikan), 2 (3), 237242. 


\section{PENDAHULUAN}

Pendidikan merupakan salah satu hal yang sangat penting dalam menentukan kualitas sumberdaya manusia (SDM). Tujuan pendidikan nasional berdasarkan Undang-Undang Republik Indonesia tentang Sistem Pendidikan Nasional pasal 3 nomor 20 tahun 2003 yaitu "Mengembangkan potensi peserta didik agar menjadi manusia yang beriman dan bertaqwa kepada Tuhan Yang Maha Esa, berakhlak mulia, sehat, cakap, kreatif, mandiri dan menjadi warga negara yang demokratis serta bertanggung jawab".

Matematika merupakan suatu komponen mata pelajaran yang mempunyai peranan penting dalam pendidikan. Pendidikan matematika dapat melatih siswa untuk berpikir, bernalar, berargumentasi dan bernegosiasi serta memecahkan suatu masalah. Menurut Sugiyono (2015), kemampuan matematis siswa diklasifikasikan ke dalam lima kompetensi utama yaitu: pemahaman, pemecahan masalah, komunikasi, penalaran, dan koneksi. Oleh karena itu, maka perlu dikembangkan pemahaman siswa dalam pembelajaran matematika. Kemampuan pemahaman merupakan kemampuan awal yang harus dimiliki oleh siswa dalam pembelajaran matematika. Menurut Carin dan Sund (dalam Susanto, 2013) pemahaman merupakan kemampuan untuk menerangkan dan menginterpretasikan sesuatu, yang berarti bahwa seseorang telah memahami sesuatu atau telah memperoleh pemahaman akan mampu menerangkan atau menjelaskan kembali apa yang telah ia terima. Bloom (Sagala, 2011) menyatakan bahwa pemahaman (comprehension) mengacu pada kemampuan untuk mengerti dan memahami sesuatu setelah sesuatu itu terlebih dahulu diketahui atau diingat dan memaknai arti dari materi yang dipelajari.

Hendriana \& Soemarmo (2014) mendefinisikan pemahaman matematis adalah kecakapan atau kemahiran menerapkan konsep/prinsip dalam menyelesaikan permasalahan matematika dan ilmu pengetahuan lain.Kemampuan pemahaman matematis merupakan suatu komponen kemampuan yang sangat penting dan harus dimiliki siswa dalam belajar matematika. Pentingnya memiliki kemampuan pemahaman matematis tercantum dalam tujuan pembelajaran matematika Kurikulum Matematika SMP (KTSP 2006 dan Kurikulum 2013). Menurut Hudoyo (2003) mengenai pentingnya memiliki kemampuan pemahaman matematis, yaitu: Tujuan mengajar matematika adalah agar pengetahuan yang disampaikan dapat dipahami peserta didik. Pendidikan yang baik adalah usaha yang berhasil membawa siswa kepada tujuan yang ingin dicapai yaitu agar bahan yang disampaikan dipahami sepenuhnya oleh siswa. Dengan demikian, pemahaman matematis merupakan landasan penting untuk berpikir dalam menyelesaikan persoalan-persoalan matematika maupun masalah kehidupan nyata. Selain itu, kemampuan pemahaman matematis sangat mendukung pada pengembangan kemampuan matematis lainnya.

Polya (Sumarmo, 2012) merinci kemampuan pemahaman pada empat tingkat yaitu: (a) Pemahaman mekanikal yang dicirikan oleh kegiatan mengingat dan menerapkan rumus secara rutin dan menghitung secara sederhana; (b) Pemahaman induktif: menerapkan rumus atau konsep dalam kasus sederhana atau dalam kasus serupa; (c) Pemahaman rasional: membuktikan kebenaran suatu rumus dan teorema; serta (d) Pemahaman intuitif: memperkirakan kebenaran dengan pasti (tanpa ragu-ragu) sebelum menganalisis lebih lanjut.

Ruang lingkup materi adalah kompetensi dasar yang diterapkan untuk setiap muatan yang sebagaimana diatur dalam Peraturan Pemerintah Nomor 32 Tahun 2013 tentang perubahan atas Peraturan Pemerintah Nomor 19 Tahun 2005 Tentang Standar Nasional Pendidikan bahwa ruang lingkup muatan matematika di SMP. Berdasakan silabus Kurikulum 2013 edisi revisi 2017, materi aljabar merupakan salah satu materi yang diajarkan kepada siswa kelas VII SMP. Kompetensi dasar yang harus dipelajari siswa yaitu menjelaskan bentuk aljabar dan melakukan operasi pada aljabar (penjumlahan, pengurangan, perkalian, dan pembagian).

Berdasarkan hasil wawancara yang dilakukan oleh peneliti terhadap guru mata pelajaran matematika kelas VII di salah satu SMP yang berada di kecamatan Culamega kabupaten Tasikmalaya menyatakan bahwa kemampuan pemahaman matematis siswa berdasarkan hasil ulangan harian dan ulangan akhir semester, bahwa siswa yang memiliki kemampuan pemahaman 
matematis bervariasi ada yang tinggi, sedang dan rendah. Penelitian ini diharapkan dapat memberikan gambaran yang lebih spesifik dengan mengelompokkan objek penelitian berdasarkan kemampuan pemahaman matematisnya.

Tujuan penelitian ini adalah untuk mengetahui kemampuan pemahaman siswa dalam menyelesaikan soal-soal aljabar. Dalam penelitian ini, peneliti membatasi masalah hanya pada kemampuan pemahaman konsep matematis siswa pada indikator pemahaman mekanikal, pemahaman induktif , pemahaman rasional, dan pemahaman intuitif kelas VII dalam menyelesaikan soal aljabar berdasarkan indikator kemampuan pemahaman konsep matematis.

\section{METODE PENELITIAN}

Penelitian ini merupakan penelitian yang menggunakan pendekatan kualitatif dengan metode studi kasus. Menurut Creswell (2010), studi kasus merupakan penelitian yang di dalamnya peneliti menyelidiki secara cermat suatu program, kejadian, aktivitas, proses, atau sekelompok individu. Suatu kasus terikat oleh waktu dan aktiivitas dan peneliti melakukan pengumpulan data secara mendetail dengan menggunakan berbagai prosedur pengumpulan data dan dalam waktu yang telah ditentukan.

Penelitian dilakukan di SMP N 1 Culamega semester genap tahun ajaran 2020/2021. Subjek penelitian adalah siswa kelas VII sebanyak enam orang. Metode pengumpulan data meliputi: (1) tes kemampuan pemahaman matematis; (2) wawancara; (3) dokumentasi. Penelitian ini dilaksanakan pada bulan juni 2021.

Analisis data pada penelitian ini merupakan proses mencari dan menyusun secara sistematis data yang diperoleh dari hasil tes tertulis yang telah dilakukan oleh siswa, yaitu tes kemampuan pemahaman matematis. Selain itu, data hasil wawancara dengan siswa diproses dan disusun secara sistematis untuk mengonfirmasi hasil jawaban yang sudah ditulis siswa dengan langkah penyelesaian yang ada dalam pemikiran siswa.

Langkah-langkah dalam menganalisis data pada penelitian ini berpedoman pada teknik analisis data model interaksi menurut Miles \& Huberman yang mengemukakan bahwa analisis data kualitatif yaitu: (1) Reduksi Data (Data Reduction) yaitu proses pemilihan, pemusatan perhatian pada penyederhanaan, pengabstrakan, transformasi data kasar yang muncul dari catatancatatan lapangan, (2) Penyajian Data (Data Display) yaitu sekumpulan informasi tersusun yang memberikan kemungkinan adanya penarikan kesimpulan dan pengambilan tindakan, (3) Menarik Kesimpulan atau Verifikasi (Conclusion Drawing/ Verification) yaitu hasil penelitian yang menjawab fokus penelitian berdasarkan hasil analisis data.

Setelah data hasil pekerjaan siswa di analisis kemudian dipilih 6 siswa dari semua siswa yang mengerjakan soal tes kemampuan pemahaman matematis aljabar untuk diwawancarai mengenai hasil pekerjaannya. Dari 6 siswa tersebut dibagi menjadi 3 kategori yaitu kategori rendah, kategori sedang, dan kategori tinggi dengan didasarkan pada akademik yang dimiliki siswa.

\section{HASIL DAN PEMBAHASAN}

Tes kemampuan pemahaman konsep matematis siswa dilaksanakan terhadap 6 orang siswa yang memiliki kemampuan pemahaman konsep matematis tinggi, sedang dan rendah. Berikut penulis sajikan data mengenai subjek penelitian pada Tabel 1.

Tabel 1. Subjek Penelitian

\begin{tabular}{ccc}
\hline No. & Kode Siswa & $\begin{array}{c}\text { Tingkat Kemampuan } \\
\text { Matematis Siswa }\end{array}$ \\
\hline 1 & LD & Rendah \\
2 & AY & Rendah \\
3 & EL & Sedang \\
4 & DN & Sedang \\
5 & LS & Tinggi \\
\hline
\end{tabular}




\begin{tabular}{ccc}
\hline No. & Kode Siswa & $\begin{array}{c}\text { Tingkat Kemampuan } \\
\text { Matematis Siswa }\end{array}$ \\
\hline 6 & CT & Tinggi \\
\hline
\end{tabular}

Berdasarkan soal no 1 pada indikator pemahaman mekanikal yang dicirikan oleh kegiatan mengingat danmenerapkan rumus secara rutin dan menghitung secara sederhana, siswa yang memiliki kemampuan pemahaman matematis rendah, LD dan AY. Pada soal nomor 1 dengan kategori soal rendah, LD mampu mengingat rumus tetapi tidak mampu menerapkan rumus dengan tepat, sedangkan AY tidak mampu mengingat dan menerapkan rumus dengan tepat. LD dan AY tidak mampu menyelesaikan soal dengan baik.Sedangkan, siswa yang memiliki kemampuan pemahaman matematis sedang, EL dan DN mampu mengingat dan menerapkan rumus penjumlahan aljabar, meskipun terdapat pengerjaan yang kurang tepat, tetapi EL dan DN mampu memberikan kesimpulan dengan benar dan dapat dimengerti maskdunya meskipun terdapat kata yang kurang tepat.

Pada siswa yang memiliki kemampuan pemahaman matematis tinggi, LS dan CT mampu mengingat dan menerapkan rumus penjumlahan aljabar dengan tepat dan memberikan kesimpulan diakhir jawaban dengan baik.Dengan demikian, siswa yang memiliki kemampuan sedang dan tinggi, mampu mengingat dan menerapkan rumus serta mampu melakukan perhitungan dengan tepat. Siswa dengan kemampuan sedang dan tinggi mampu memberikan kesimpulan secara lisan dan tulisan dengan baik meskipun dengan menggunakan bahasa sendiri. Menurut Sarlito (2001: 55- 56) "Mengingat adalah perbuatan menyimpan hal-hal yang sudah pernah diketahui untuk pada suatu saat lain dikeluarkan dan digunakan kembali".

Berdasarkan pernyataan di atas, dapat disimpulkan bahwa hampir semua siswa mampu mengingat dan menerapkan rumus dalam kasus sederhana. Hal ini disebabkan karena siswa sering menjumpai permasalahan seperti yang terdapat pada soal no 1, yaitu seperti dalam kehidupan sehari-hari terutama dalam hal perdagangan.

Berdasarkan soal no 2 pada indikator pemahaman induktif yaitu menerapkan rumus atau konsep dalamkasus sederhana atau dalam kasus serupa, siswa yang memiliki kemampuan pemahaman matematis rendah LD dan AY, LD dan AY tidak mampu menerapkan dan melakukan perhitungan dengan tepat. Berdasarkan hasil wawancara, hal ini dikarenakan LD dan AY hanya mampu mengingat rumus yang hendak digunakan tetapi tidak bisa menerapkan rumus serta kesulitan dalam melakukan perhitungan dan menyelesaikan permasalahan dengan tepat.

Siswa yang memiliki kemampuan pemahaman matematis sedang dan tinggi, cenderung mampu menerapkan rumus dan melakukan perhitungan dengan tepat. Memecahkan suatu permasalahan merupakan suatu proses, dimana setiap individu menggunakan keahlian dan pemahaman sebelumnya yang dikembangkan dan diaplikasikan ke dalam situasi yang tidak biasa.

Dengan demikian, dapat disimpulkan bahwa siswa yang memiliki kemampuan pemahaman matematis rendah belum mampu menerapkan rumus dan melakukan perhitungan dengan tepat. Sedangkan, siswa yang memiliki kemampuan pemahaman matematis sedang dan tinggi cenderung mampu menerapkan rumus dan melakukan perhitungan dengan tepat. Setiap siswa mampu menyelesaikan permasalahan matematika menggunakan keahlian mereka sendiri berdasarkan pengalaman ataupun pengetahuan yang telah didapatkan sebelumnya. Oleh karena itu, pada pemahaman ini perhatian siswa perlu difokuskan yaitu dengan meminta siswa untuk mengingat rumus/konsep yang telah dipelajari sesuai dengan permasalahan dan melakukan tanya jawab dengan memberikan pertanyaan arahan/petunjuk dan juga meminta siswa untuk memeriksa kembali jawabannya dengan teliti.

Berdasarkan soal no 3 pada indikator pemahaman rasional yaitu membuktikan kebenaran suatu rumusdan teorema. Berdasarkan hasil analisis, siswa yang memiliki kemampuan pemahaman matematis rendah, sedang, dan tinggi, mereka cenderung kurang mampu membuktikan kebenaran suatu rumus dan teorema. Dalam membuktikan rumus, siswa membuat kembali soal tersebut. 
Berdasarkan wawancara, siswa cenderung kurang memahami bagaimana cara membuktikan rumus dengan tepat, hal ini disebabkan karena siswa kurang mendapatkan informasi atau pengetahuan mengenai hal tersebut. Siswa tidak terbiasa dalam membuktikan kebenaran suatu rumus/teorema, siswa hanya mendapatkan rumus secara langsung tanpa mengetahui prosesnya.

Dengan demikian, dapat disimpulkan bahwa hampir semua siswa belum mampu membuktikan kebenaran rumus atau teorema dengan tepat. Kurangnya pemahaman siswa dalam membuktikan rumus/teorema disebabkan oleh kurangnya penekanan atau pemantapan materi yang lebih mendalam. Menurut Piaget (dalam Dahar, 2011) "periode perkembangan kognitif pada tahapan operasional formal, karakteristik pada tahap ini adalah diperolehnya kemampuan berpikir secara abstrak, menalar secara logis, dan menarik kesimpulan dari informasi yang tersedia". Selain daripada itu, siswa perlu diarahkan agar lebih berpikir keras untuk membuktikan hasil perhitungan berdasarkan konsep yang telah dipelajari, sehingga siswa akan terbiasa dalam membuktikan kebenaran hasil jawabannya.

Berdasarkan soal no 4 pada indikator pemahaman intuitif yaitu memperkirakan kebenaran dengan pasti(tanpa ragu-ragu) sebelum menganalisis lebih lanjut, Siswa yang memiliki kemampuan pemahaman matematis rendah, LD dan AY mampu mempekirakan kebenaran hasil (jawaban) dengan baik, tetapi kurang mampu memperkirakan dengan pasti (masih ragu-ragu) rumus yang digunakan. Berdasarkan hasil wawancara, LD kurang mampu memahami isi soal, sedangkan AY kurang mampu memahami langkah-langkah pengerjaan dalam menyelesaikan permasalahan.

Siswa yang memiliki kemampuan pemahaman matematis sedang dan tinggi, cenderung mampu memperkirakan kebenaran (jawaban) dengan pasti (tanpa ragu-ragu). Meskipun terdapat siswa yang kurang mampu memperkirakan rumus yang hendak digunakan dalam perhitungan, tetapi pada umumnya siswa yang termasuk dalam kategori ini, mampu menyelesaikan soal dengan baik dan tepat serta mampu menyimpulkan jawaban dengan jelas.

Dengan demikian, dapat disimpulkan bahwa hampir semua siswa mampu memperkirakan kebenaran rumus (jawaban) meskipun terdapat beberapa siswa yang kurang mampu dalam memperkirakan dengan pasti rumus yang hendak digunakan. Oleh karena itu, untuk meningkatkan pemahaman intuitif siswa perlu ditekankan untuk memeriksa kembali hasil pekerjaannya, siswa perlu diarahkan untuk memberikan kesimpulan dengan benar, serta agar siswa lebih mampu dalam memahami konsep dengan benar maka perlu ditingkatkannya pemberian soal latihan dengan permasalahan yang bervariasi.

\section{KESIMPULAN}

Berdasarkan hasil penelitian dan pembahasan, dapat diambil simpulan bahwa hampir semua siswa berkategori rendah, sedang dan tinggi mampu mengingat dan menerapkan rumus secara rutin dan menghitung secara sederhana (Pemahaman Mekanikal). Siswa dengan kemampuan pemahaman matematis sedang dan tinggi cenderung mampu menerapkan rumus dan melakukan perhitungan dengan tepat. Sedangkan siswa dengan kemampuan pemahaman matematis rendah belum mampu menerapkan rumus dan melakukan perhitungan dengan tepat (Pemahaman Induktif). Hampir semua siswa berkategori rendah, sedang dan tinggi belum mampu membuktikan kebenaran suatu rumus atau teorema (Pemahaman Rasional). Dan hampir semua siswa berkategori rendah, sedang dan tinggi mampu memperkirakan kebenaran rumus (jawaban) meskipun terdapat beberapa siswa yang kurang mampu dalam memperkirakan dengan pasti rumus yang hendak digunakan (Pemahaman Intuitif).

\section{REKOMENDASI}

Penelitian ini meneliki keempat indikator kemampuan pemahaman konsep matematis yakni pemahaman mekanikal, pemahaman induktif, pemahaman rasional, dan pemahaman intuitifdikarenakan karakteristik dari materinya sesuai, untuk penelitian pada materi lainnya maka sebaiknya memperhatikan kesesuaian antara indicator dan karakteristik materi. 


\section{UCAPAN TERIMAKASIH}

Peneliti mengucapkan terimakasih kepada kepala SMP N 1 Culamega dan siswa kelas VII SMP N 1 Culamega Kecamatan Culamega Kabupaten Tasikmalaya tahun akademik 2020/2021 karena telah mendukung terhadap pelaksanaan penelitian ini. Selain itu, ucapan terimakasih juga ditujukan kepada pembimbing dan menejemen program studi pendidikan matematika yang telah memberikan arahan dan motivasi kepada peneliti untuk menyelesaikan penelitian ini.

\section{DAFTAR PUSTAKA}

Creswell, J. W. (2010). Research design: pendekatan kualitatif, kuantitatif, dan mixed. Yogyakarta: PT Pustaka Pelajar.

Dahar, R. W. (2011). Teori-Teori Belajar \& Pembelajaran. Jakarta: Erlangga.

Depdiknas. (2003). Sistem Pendidikan Nasional. Retrieved from kelembagaan.ristekdikti.go.id (pdf). [08 Desember 2018].

Hendriana, H., \& Soemarmo, U. (2014). Penilaian Pembelajaran Matematika. Bandung: Refika Aditama.

Hudoyo, H. (2003). Pengembangan Kurikulum dan Pembelajaran Matematika. Malang: Universitas Negeri Malang.

Sagala, S. (2011). Konsep dan Makna Pembelajaran. Bandung: Alfabeta

Sugiyono. (2015). Metode penelitian \& pengembangan (research and development). Bandung: Alfabeta.

Sumarmo. (2012), Kemampuan dan Disposisi Berpikir Logis, Kritis, dan Kreatif Matematik, Jurnal Pengajaran MIPA Vol 17 No. 1: 17-33.

Susanto, A. (2013). Teori Belajar \& Pembelajaran di Sekolah Dasar. Jakarta: Kencana 